\title{
THE LIVER IN RHEUMATOID ARTHRITIS
}

\author{
BY
}

\author{
AARON M. LEFKOVITS AND IRVING J. FARROW \\ From the General Medicine and Rheumatology Section of the Medical Service, \\ Veterans Administration Medical Teaching Group Hospital (Kennedy), Memphis, Tennessee
}

(RECEIVED FOR PUBLICATION JANUARY 18, 1955)

It is generally recognized that rheumatoid arthritis is a systemic disease characterized by profound and widespread disturbances in the connective tissues throughout the body, but having a special predilection for the periarticular and articular structures. Because the supporting framework of parenchymal organs is made up of connective tissue elements, it has been suspected that the function of these organs is altered in patients with rheumatoid arthritis as a result of direct involvement of the supporting framework and/or by secondary morphological alterations of the parenchymatous elements. Thus, the liver has been the subject of investigation by several observers, and its function has been studied to determine whether this organ is involved in patients with rheumatoid arthritis. With the newer techniques of biopsy, liver tissue can be obtained with greater ease, so that the morphologic alterations in the liver may be studied and correlated with liver function tests in patients with various diseases.

The purpose of this report is to present our experience with some laboratory procedures designed to test some of the functions of the liver in one hundred patients with rheumatoid arthritis, and to report the results of examination of liver tissue obtained by needle biopsy in twelve of these patients, and the post-mortem findings in the liver of an additional three of these patients.

\section{Review of the Literature}

A review of the existing literature relating to the involvement of the liver in rheumatoid arthritis reveals inadequate or contradictory information.

Davis (1936) found a high incidence of increased levels of globulin and decreased levels of albumin in the plasma of patients with rheumatoid arthritis. The blood fibrinogen level was also found to be increased in these patients and there was an inverse relationship between the fibrinogen and globulin levels. Rawls and others (1937) used the azorubin $S$ test as an index of liver function in one hundred patients who had "severe", "moderately severe", or "mild" rheumatoid arthritis: 27 of 34 severe cases (73 per cent.), 21 of 44 moderately severe cases (47.5 per cent.), and seven of 22 mild cases. $\vec{\circ}$ $(25 \cdot 25$ per cent.), amounting to 55 per cent. of the entire $\overrightarrow{\vec{H}}$ group, showed liver dysfunction. In addition, these ${ }_{\mathscr{S}}$ authors also found a slight reduction of the serum@ proteins and a reversal of the $A / G$ ratio in most of those? cases (number not mentioned) that showed liver dys- $\vec{A}$ function. They found no correlation between the dura- $\dot{\sim}$ tion of the disease and impairment of liver function, but $\vec{\sim}$ liver dysfunction was found more frequently in patients $\mathrm{N}$ who had more severe rheumatoid arthritis.

Rawls and others (1939) reported on the results of $\rightarrow$ several liver function tests in fifty unselected cases of $\underset{C}{ }$ rheumatoid arthritis. The azorubin $\mathrm{S}$ test showed some evidence of liver dysfunction in 60 per cent.; the hippuric ${ }^{\infty}$ acid excretion (Quick method) was abnormal in 62 per $\vec{c}$ cent. The bilirubin excretion (Soffer and Paulson G method) was abnormal in twelve of 25 cases (48 per centg; the galactose tolerance test (excretion of $2 \mathrm{~g}$. or more) waso abnormal in seven of 25 patients (14 per cent.); icteric index (index 8 considered normal) was abnormatio in 22 cases (44 per cent.); the serum albumin level was abnormal ( $4 \mathrm{~g} . / 100 \mathrm{ml}$. or less) in 34 cases (68 per cent.); $\stackrel{\mathbb{Q}}{\varrho}$ the $\mathrm{A} / \mathrm{G}$ ratio was abnormal (less than 2) in 38 cases $\Rightarrow$ (76 per cent.). The azorubin $S$ test agreed more closely with the clinical evidence of liver damage than any other single test.

Baggenstoss and Rosenberg (1943) reported on the post-mortem findings in thirty patients with rheumatoid arthritis whose death was due to various causes. The? most frequently observed hepatic lesions were gross $\frac{3}{3}$ atrophy or hypertrophy, chronic passive congestion, fatty changes, "serous hepatitis", and central necrosis. These changes were associated with heart disease and/or inanition. They found no evidence to suggest that the reticulo-endothelial system was stimulated in these patients, nor did they find "any hepatic lesion which could be considered specific".

Perlmann and Kaufman (1946) investigated the serum $N$ protein electrophoresis in 23 patients with rheumatoid arthritis. The results suggested an elevation of $\alpha$ 궁 globulins during the early course of the disease followed $\mathrm{C}$ by a predominance in $\gamma$ globulins in later stages.

Carter and Maclagan (1946) found the serum colloidak gold test to be positive in 76 per cent. and the thymol turbidity test to be positive in 38 per cent. of 34 patients $\stackrel{\leftrightarrow}{\longrightarrow}$ with "atrophic type" of arthritis.

Kalbak (1951) found positive thymol reactions in $\frac{0}{0}$ 75 per cent. of 21 patients with rheumatoid arthritis; $\frac{\mathbb{Q}}{\mathbb{Q}}$ 
in four, the positive thymol reaction became normal during treatment with cortisone or ACTH. He thought that the positive thymol reaction was due to change in serum proteins.

Archer (1951) found the cephalin flocculation and thymol turbidity tests to be consistently negative in ten patients with rheumatoid arthritis, and in two other patients with both rheumatoid arthritis and degenerative joint disease; the total serum proteins and serum albumin were normal, and the serum globulin tended to be raised. He emphasized that the lowering of the $A / G$ ratio in "non-specific" arthritis was the result of a raised globulin level alone and not of a diminished albumin level.

Schmengler (1952) reported on the findings of liver involvement in thirty cases of "chronic rheumatism"; one of which was examined post mortem. The liver was palpable in 21 ; the Takata reaction was positive in fifteen of the twenty patients; the thymol turbidity test was positive in "most cases". Electrophoretic partition of serum proteins was done in 23: the $\gamma$ globulin was increased in 70 per cent., the $\beta$ globulin in 26 per cent., and the $\alpha$ globulin in 35 per cent. Liver tissue was examined in the one autopsied case and in 27 patients obtained by biopsy through the peritoneoscope. In two patients, attempt at biopsy was unsuccessful. All liver specimens were abnormal. Grossly, the liver appeared greyish-red with loss of glistening; the surface was irregular and presented scars, fibrous bands, or reticular arrangement. Microscopically, the cells showed variations in size, fatty degeneration, "reactions of Kupffer cells", haemosiderin accumulations here and there, at times necrosis, perivascular round cell infiltrations, increase in fibrous tissue, and transformation into "rheumatic hepatitis" and cirrhosis.

Movitt and Davis (1953) found no significant abnormalities in the serum albumin level, cephalin flocculation tests, and prothrombin concentrations, or in the morphology of the liver obtained by needle biopsy in seventeen male patients with rheumatoid arthritis, but the incidence of raised serum globulin was high.

The observations relating to the ameliorating influence of liver disease with or without jaundice, pregnancy, and several other diseases upon the manifestations of rheumatoid arthritis are of interest in this connexion. These are adequately discussed by Hench (1940) and will not be repeated here. They led indirectly to the investigations which resulted in the discovery of the beneficial, although temporary, effect of adrenal steroids and ACTH upon the manifestations of rheumatic diseases.

It is readily seen from the foregoing that the results obtained by these investigators have not given us a definite answer to the question whether the liver is involved by the rheumatoid disease process? Our attempts at resolving this problem are hindered mainly by the following difficulties:

(1) Non-hepatic diseases altering the results of so-called liver function tests;

(2) Our inability to distinguish between the effects of systemic disease processes upon the liver and intrinsic liver disease by the available tests of liver function;

(3) The inadequacy of the available histological methods of examination of liver tissue obtained, either by biopsy or post mortem, to reveal functional alterations or impairment.

\section{Methods of Study and Procedures}

One hundred male patients with rheumatoid arthritis at different stages of severity were observed in the hospital; 77 had involvement of the peripheral joints only, nine had involvement of both peripheral joints and spine, and fourteen had involvement of the spine only. The age of the patients, and duration, stage, and grade of severity of the disease are indicated in Table I.

TABLE I

DISTRIBUTION OF PATIENTS ACCORDING TO AGE, STAGE, SEVERITY, AND DURATION OF DISEASE

\begin{tabular}{|c|c|c|c|c|c|c|c|}
\hline \multirow{2}{*}{$\begin{array}{c}\text { Stage } \\
\text { of } \\
\text { Disease }\end{array}$} & \multirow{2}{*}{$\begin{array}{c}\text { No. } \\
\text { of } \\
\text { Patients }\end{array}$} & \multirow{2}{*}{$\begin{array}{c}\text { Age } \\
\text { Group } \\
\text { (yrs) }\end{array}$} & \multirow{2}{*}{$\begin{array}{l}\text { Duration of } \\
\text { Disease } \\
\text { (range) }\end{array}$} & \multicolumn{4}{|c|}{ Severity of Disease } \\
\hline & & & & I & II & III & IV \\
\hline $\begin{array}{l}\text { I } \\
\text { II } \\
\text { III } \\
\text { IV }\end{array}$ & $\begin{array}{l}20 \\
30 \\
22 \\
14\end{array}$ & $\begin{array}{l}22-64 \\
24-63 \\
25-65 \\
28-66\end{array}$ & $\begin{array}{l}6 \mathrm{wks}-10 \mathrm{yrs} \\
3 \mathrm{mths}-20 \mathrm{yrs} \\
8 \mathrm{mths}-35 \mathrm{yrs} \\
1 \mathrm{yr}-35 \mathrm{yrs}\end{array}$ & $\begin{array}{l}- \\
-\end{array}$ & $\begin{array}{r}5 \\
4 \\
- \\
-\end{array}$ & $\begin{array}{l}10 \\
13 \\
14 \\
\end{array}$ & $\begin{array}{r}5 \\
13 \\
8 \\
14\end{array}$ \\
\hline - & $14^{*}$ & $20-55$ & $-16 \mathrm{yrs}$ & - & - & - & - \\
\hline & & & & - & 9 & 37 & 60 \\
\hline
\end{tabular}

* Spinal involvement only.

The severity of the disease and resulting functional impairment of the 86 patients who had peripheral joint involvement are graded in accordance with the therapeutic criteria of the American Rheumatism Association (Steinbrocker and others, 1949). The liver function tests, the method of their determination, and the considered normal values are indicated in Table II.

TABLE II

LIVER FUNCTION TESTS

\begin{tabular}{|c|c|c|}
\hline Type of Test & Method & Normal Values \\
\hline Serum bilirubin & $\begin{array}{c}\text { Evelyn and Malloy, } \\
1937\end{array}$ & $0.2-0.8 \mathrm{mg}$. per cent. \\
\hline $\begin{array}{l}\text { Serum phosphatase } \\
\text { (alkaline) }\end{array}$ & Bodansky, 1933 & 2-4 Bodansky units \\
\hline Bromsulphalein & $\begin{array}{l}\text { Rosenthal and White, } \\
1925\end{array}$ & $\begin{array}{l}\text { Not over } 1.6 \text { per cent. } \\
\text { in } 45 \mathrm{~min} \text {. (using } \\
5 \mathrm{mg} . / \mathrm{kg} \text {. body- } \\
\text { weight) }\end{array}$ \\
\hline $\begin{array}{l}\text { Total protein, albu- } \\
\text { min, and globulin }\end{array}$ & $\begin{array}{l}\text { Wolfson, Cohen, } \\
\text { Calvary, and } \\
\text { Ichiba, } 1948\end{array}$ & $\begin{array}{l}\text { 6-8 g./100 ml. } \\
\text { (Alb. 3.4-4.5 g./ } \\
100 \text { ml.; Glob. } \\
2 \cdot 3-3 \cdot 6 \text { g. } / 100 \mathrm{ml} .)\end{array}$ \\
\hline Cephalin flocculation & Hanger, 1939 & $\begin{array}{l}\text { Not over } 2 \text { per cent. } \\
\text { in } 48 \mathrm{hrs}\end{array}$ \\
\hline Thymol turbidity & $\begin{array}{l}\text { Ley, Lewis, and } \\
\text { Davidson, } 1946\end{array}$ & $\begin{array}{l}\text { Above } 1 \cdot 4 \mathrm{ml} . \mathrm{BaSO}_{4} \\
\text { or above } 5 \text { turbidity } \\
\text { units }\end{array}$ \\
\hline Prothrombin & $\begin{array}{l}\text { Quick (one stage), } \\
\text { Fisher, } 1947\end{array}$ & 100 per cent. \\
\hline Total cholesterol & $\begin{array}{l}\text { Bloor, Pelkan, and } \\
\text { Allen, } 1922\end{array}$ & $150-250 \mathrm{mg}$. per cent. \\
\hline
\end{tabular}


Table III shows the patients in whom each type of test was determined, and the patients with peripheral joint involvement are grouped according to the stage of their disease. Twelve patients with involvement of

TABLE III

TYPE AND TOTAL NUMBER OF LIVER FUNCTION TESTS DETERMINED

\begin{tabular}{|c|c|c|c|c|c|c|}
\hline \multirow{3}{*}{$\begin{array}{c}\text { Type of } \\
\text { Test } \\
\text { Only }\end{array}$} & \multirow{2}{*}{\multicolumn{4}{|c|}{$\begin{array}{c}\begin{array}{c}\text { Peripheral } \\
\text { Joint Involvement }\end{array} \\
\text { Stage of Disease }\end{array}$}} & \multirow{3}{*}{$\begin{array}{c}\text { Spinal } \\
\text { Involve- } \\
\text { ment } \\
\text { Only }\end{array}$} & \multirow{3}{*}{$\begin{array}{l}\text { Total } \\
\text { Tests }\end{array}$} \\
\hline & & & & & & \\
\hline & I & II & III & IV & & \\
\hline Serum bilirubin . & 9 & 22 & 18 & 9 & 13 & 71 \\
\hline $\begin{array}{l}\text { Alkaline phos- } \\
\text { phatase }\end{array}$ & 7 & 14 & 10 & 11 & 5 & 47 \\
\hline Bromsulphalein . . & 9 & 25 & 22 & 12 & 6 & 74 \\
\hline Protein .. & 18 & 27 & 21 & 13 & 12 & 91 \\
\hline Albumin.. & 18 & 27 & 21 & 13 & 12 & 91 \\
\hline Globulin. . & 18 & 27 & 21 & 13 & 12 & 91 \\
\hline $\begin{array}{l}\text { Cephalin } \\
\text { flocculation }\end{array}$ & 10 & 26 & 22 & 12 & 11 & 81 \\
\hline Thymol turbidity & 11 & 28 & 19 & 12 & 12 & 83 \\
\hline Prothrombin & 9 & 27 & 21 & 11 & 7 & 75 \\
\hline Cholesterol & 9 & 20 & 15 & 10 & 11 & 65 \\
\hline
\end{tabular}

peripheral joints had Vim-Silverman needle biopsies of the liver performed by the transthoracic approach.* In an additional three patients, liver tissue was obtained post mortem; two of these patients had severe crippling deformities of the peripheral joints with extensive osteoporosis: one had compression of the spinal cord by collapsed osteoporotic cervical vertebrae and died as a result of pneumonia; the other also died of pneumonia but had, in addition, severe coronary artery disease. The third patient had spinal involvement only and presented the characteristic appearance of "bamboospine"; he had severe hypertensive cardiovascular disease and died as a result of rupture of dissecting aneurysm of the arch of the aorta. The pertinent clinical and laboratory data of these fifteen patients are indicated in Table IV.

\section{Results}

Table $\mathrm{V}$ (overleaf) indicates the type and number of abnormal results grouped by stage of disease. It is readily seen that there is a direct relationship between the severity of the disease, as indicated by the stage of the disease, and the number of abnormal results. Of twenty patients with Stage I rheumatoid arthritis, thirteen (65 per cent.) had

* These biopsies were performed by the members of the Gastrointestinal Section of the hospital. The liver tissue was fixed in 10 per cent. formalin and stained with haematoxylin and eosin in the usual manner.

SUMMARY OF PERTINENT CLINICAL AND LABORATORY DATA AND MORPHOLOGICAL ALTERATION

\begin{tabular}{|c|c|c|c|c|c|c|c|c|}
\hline $\begin{array}{l}\text { Patient } \\
\text { No. }\end{array}$ & $\underset{\text { (yrs) }}{\text { Age }}$ & $\begin{array}{l}\text { Severity } \\
\text { of } \\
\text { Disease }\end{array}$ & $\begin{array}{c}\text { Duration of } \\
\text { Disease } \\
\text { (yrs) }\end{array}$ & $\begin{array}{c}\text { Erythrocyte } \\
\text { Sedimentation } \\
\text { Rate } \\
\text { (mm./hr) } \\
\text { (Wintrobe) }\end{array}$ & $\underset{\text { Silirumin }}{\text { Serum }}$ & $\begin{array}{c}\text { Alkaline } \\
\text { Phosphatase } \\
\text { (Bodansky } \\
\text { units) }\end{array}$ & $\begin{array}{c}\text { Bromo } \\
\text { Sulphalein } \\
\text { (per cent.) }\end{array}$ & Albumin \\
\hline 1 & 46 & II & 6 & 34 & 0.5 & $1 \cdot 3$ & Neg. & $3 \cdot 8$ \\
\hline $2^{*}$ & 35 & II & $5 / 12$ & 36 & 0.39 & $3 \cdot 35$ & 20 & $3 \cdot 3$ \\
\hline 3 & 28 & II & 6 & 28 & $0 \cdot 48$ & 1.7 & Neg. & $4 \cdot 6$ \\
\hline $\begin{array}{l}4 \\
5 \\
6^{*}\end{array}$ & $\begin{array}{l}33 \\
58 \\
57\end{array}$ & $\begin{array}{l}\text { II } \\
\text { II } \\
\text { II }\end{array}$ & $\begin{array}{r}7 \\
5 \\
17\end{array}$ & $\begin{array}{l}23 \\
34 \\
36\end{array}$ & $\begin{array}{l}0.7 \\
0.5 \\
-\end{array}$ & $\overline{1 \cdot 8}$ & $\begin{array}{l}\text { Neg. } \\
20 \\
\text { Neg. }\end{array}$ & $\begin{array}{l}3 \cdot 9 \\
3 \cdot 5 \\
3 \cdot 8\end{array}$ \\
\hline $\begin{array}{l}7 \\
8\end{array}$ & $\begin{array}{l}32 \\
54\end{array}$ & $\begin{array}{l}\text { III } \\
\text { III }\end{array}$ & $\begin{array}{l}8 \\
4\end{array}$ & $\begin{array}{l}35 \\
30\end{array}$ & $\begin{array}{l}0.5 \\
0.54\end{array}$ & $\begin{array}{l}1.55 \\
1.2\end{array}$ & $\begin{array}{c}\text { Neg. } \\
15\end{array}$ & $\begin{array}{l}3 \cdot 4 \\
3 \cdot 6\end{array}$ \\
\hline 9 & 44 & III & 5 & 32 & 0.7 & - & Neg. & $4 \cdot 2$ \\
\hline $\begin{array}{l}10 \\
11\end{array}$ & $\begin{array}{l}55 \\
44\end{array}$ & $\begin{array}{l}\text { III } \\
\text { III }\end{array}$ & $\begin{array}{l}4 \\
8\end{array}$ & $\begin{array}{l}35 \\
37\end{array}$ & 0.1 & $\overline{-}$ & $\begin{array}{r}75 \\
\text { Neg. }\end{array}$ & $\begin{array}{l}3 \cdot 1 \\
3 \cdot 4\end{array}$ \\
\hline 12 & 62 & IV & 21 & 23 & 0.5 & $3 \cdot 8$ & Neg. & - \\
\hline $13^{*} \dagger$ & 58 & IV & 18 & 28 & $0 \cdot 39$ & 1.2 & 1.8 & 2.9 \\
\hline $14^{*} \dagger$ & 55 & IV & 6 & 36 & - & $5 \cdot 1$ & 75 & 3.6 \\
\hline $15 \dagger$ & 55 & - & 26 & 28 & 0.8 & - & - & 3.7 \\
\hline
\end{tabular}


abnormal results. Of thirty patients in Stage II, 26 (86.66 per cent.) had abnormal results. Of 22 patients in Stage III, 21 (95.45 per cent.) had abnormal results. All fourteen patients in Stage IV had abnormal results.

Depression of the serum albumin level was the most frequently found abnormality in Stage I patients. In Stage II patients a raised serum globulin level was the most frequent abnormality (seen in 12), and the serum albumin level was depressed in ten. Similar changes in the albumin and globulin levels were found in Stage III and IV patients.

The cephalin flocculation test was abnormal in five of 26 Stage II patients (19 per cent.). The thymol turbidity test was abnormal in five of 28 Stage II patients $(17 \cdot 8$ per cent.). The cephalin flocculation test was abnormal in seven of 22 Stage III patients ( $31 \cdot 8$ per cent.), and the thymol turbidity in six of nineteen Stage III patients (31.5 per cent.). The cephalin flocculation test was abnormal in six of twelve Stage IV patients ( 50 per cent.), but thymol turbidity test was abnormal only in one of thirteen Stage IV patients.

The serum cholesterol level was raised in approximately 50 per cent. of Stage I and II patients, but in only three of fifteen patients ( 20 per cent.) and in only one of ten Stage IV patients.
The serum bilirubin level was normal in all the patients (58 with peripheral joint involvement and thirteen with spinal involvement) in whom it was determined.

The bromosulphalein test was normal in all Stage I patients; it was abnormal in six Stage II patients (24 per cent.), five Stage III patients ( $22 \cdot 7$ per cent.), and three Stage IV patients ( 25 per cent.).

Of the fourteen patients who had only spinal involvement, six showed abnormalities in a total of eleven abnormal results, as indicated in Table $\mathrm{V}$.

Microscopic examination of tissue obtained by biopsy in the twelve patients in whom this was performed revealed only minor alterations, chiefly variations in the size and pigmentation of the nuclei of the liver cells, slight prominence of the peripheral fibrous tissue with slight but varying degrees of round cell infiltration, and, occasionally, slight increase of fat. In two of these specimens, these alterations were more pronounced; Figs 1 and 2 (overleaf) depict the most marked of these changes.

In none of these biopsies was the pathologist* able to discern definite evidence of cirrhosis.

* Dr. Joseph M. Young, Pathologist, Veterans Administration Medical Teaching Group (Kennedy) Hospital.

JF PATIENTS IN WHOM LIVER TISSUE WAS AVAILABLE FOR EXAMINATION BY BIOPSY OR AT POST-MORTEM

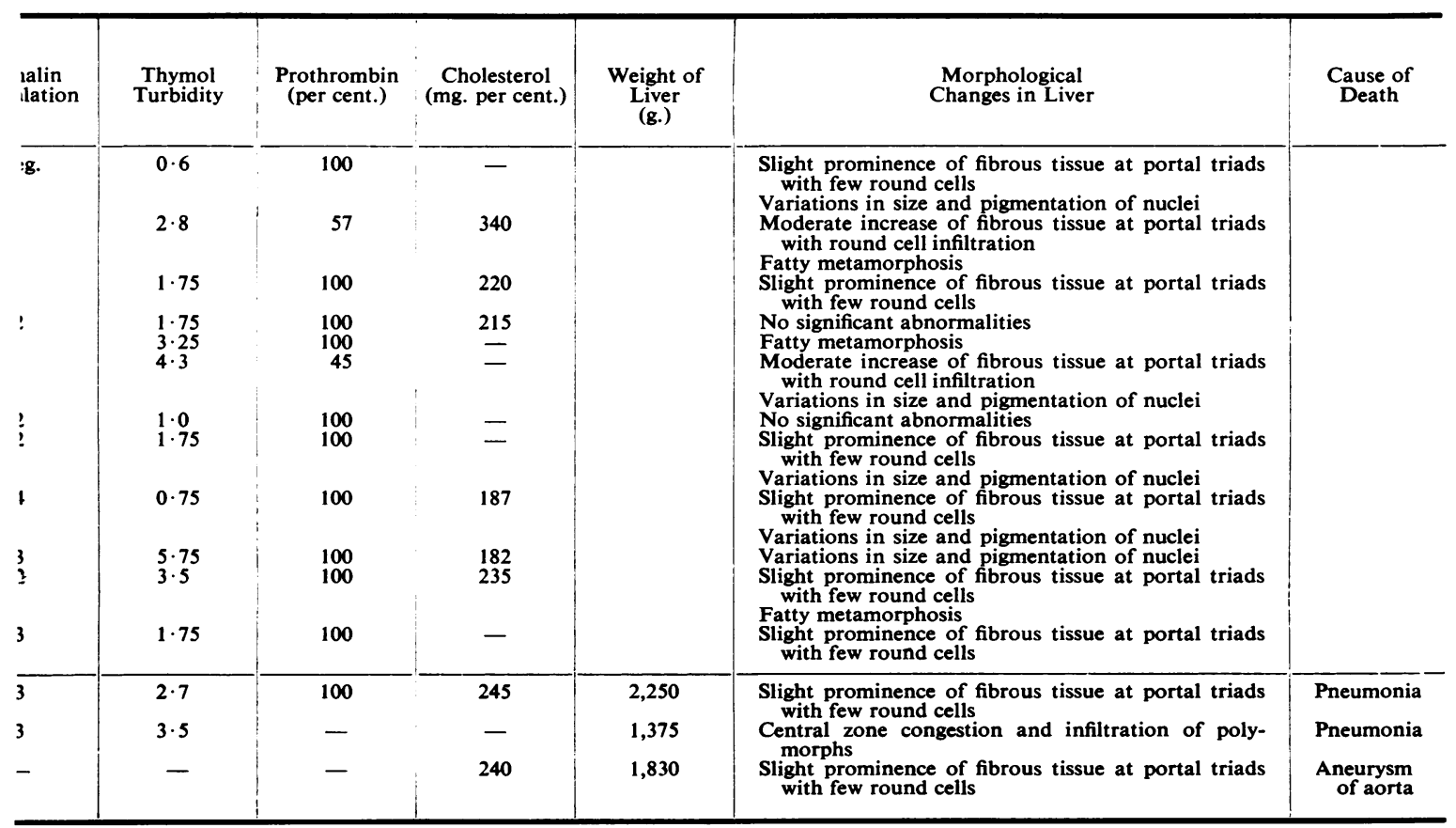


TABLE $\mathrm{V}$

ABNORMAL LIVER FUNCTION RESULTS, SHOWN WITH NUMBER OF PATIENTS TESTED

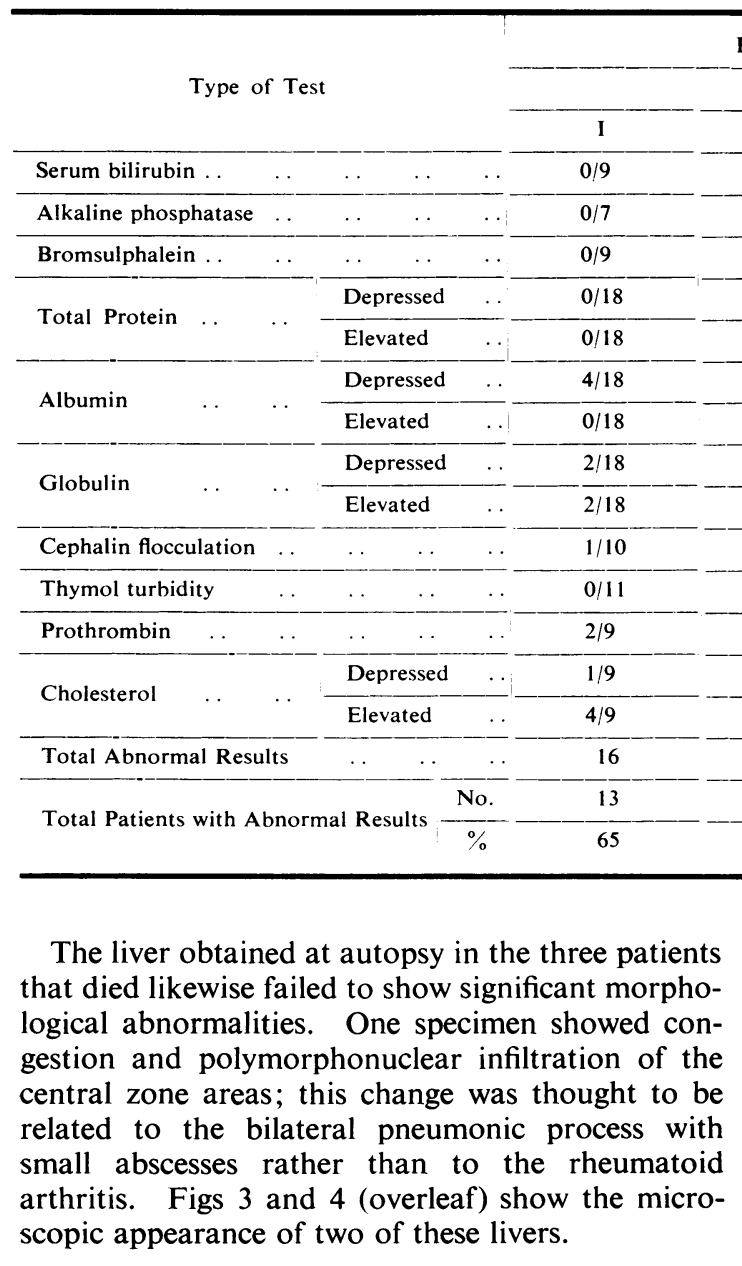

\section{Comment}

The results suggest that there is a relationship between the severity of rheumatoid arthritis and the hepatic dysfunction indicated by certain liver function tests. Elevation of the serum globulin and depression of the serum albumin were the most frequent abnormalities, closely followed by abnormal cephalin flocculation and thymol turbidity tests. The other tests did not indicate abnormalities in a sufficient number of patients to be of statistical significance. Abnormal liver function tests were found infrequently in patients who had only spinal involvement. Histological examination of the available liver tissue in fifteen of these patients showed only minor alterations. None of the three liver

Peripheral Joint Involvement

Stage of Disease

\begin{tabular}{|c|c|c|c|}
\hline II & III & IV & Only \\
\hline $0 / 22$ & $0 / 18$ & $0 / 9$ & $0 / 13$ \\
\hline $0 / 14$ & $1 / 10$ & $2 / 11$ & $9 / 5$ \\
\hline $6 / 25$ & $5 / 22$ & $3 / 12$ & $0 / 6$ \\
\hline
\end{tabular}

$3 / 27$

$12 \ldots$

$4 / 27 \quad 1 / 13 \quad 1 / 12$

$10 / 27$

$\frac{2 / 27}{2 / 27}-\frac{2 / 21}{0 / 21}-0$

$0 / 13$

$0 / 12$

$12 / 27$

$-\frac{0 / 2}{12 / 21}$

$\frac{5 / 26}{5 / 28}-\frac{7 / 22}{6 / 19}$

$11 / 13$

$6 / 27$

$6 / 19$

- - - -

$1 / 2000 / 150$

$10 / 20 \quad-3 / 15$

$\frac{66}{26}-\frac{51}{21}-\frac{38}{95 \cdot 6}-\frac{14}{100}$

specimens obtained post mortem from the three patients who died (disease of Stage IV severity, but inactive, and of 18,6 , and 26 years' duration,,$\stackrel{\mathbb{Q}}{\varrho}$ respectively) showed any significant abnormalities. $\overrightarrow{\vec{B}}$ Perhaps, however, although haematoxylin-eosin 3 stains did not depict abnormalities, other more refined methods of examination, such as electrono microscopy, special staining, and histochemical studies, would have revealed a closer correlation withộ. the liver function tests.

It is difficult to evaluate the significance of these minor morphological alterations. Such changes areo seen not infrequently in liver specimens obtained at autopsy from individuals who die of diverse con-윽 ditions in whom no evidence of liver disease could be found. At the most, these abnormalities could을. probably be designated by what Popper (1954) N termed "non-specific reactive hepatitis". There was" no strict correlation between the functions of the liver as appraised by the liver function tests used herew and the histological appearance of the liver specimens. Other investigators (Franklin and others 6 1948; Popper and others, 1950; Lichtman, 1942) have also commented upon the lack of consisten $\stackrel{?}{+}$ correlation between the clinical and laboratoryo findings in liver disease and the histological picture? 


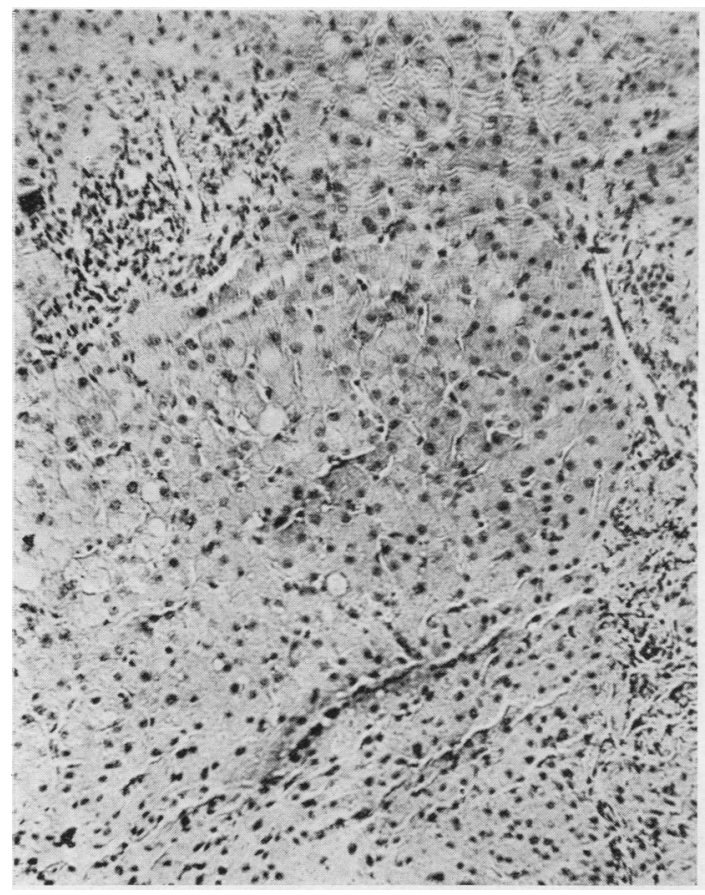

Fig. 1.-Case 2, showing moderate increase of periportal fibrous tissue, round cell infiltration, and slight fatty change.

of liver tissue. Popper (1954) noted that severe hepatic failure was at times associated with relatively few histological alterations, and, conversely, apparently intact liver function was found in patients showing widespread changes in the hepatic parenchyma. These contradictory findings are generally attributed to the fact that the haematoxylin-eosin stained liver sections probably do not depict the functional aberrations of the liver parenchyma. Moreover, the regenerative ability of the liver is so great that impairment of its function can be demonstrated only after extensive liver damage.

The utilization of the so-called liver function tests in assessing the functions of the liver is further complicated by the observation that these tests are nonspecific and are not infrequently altered in any chronic disease of whatever aetiology. The abnormal values obtained in these tests could, therefore, be considered to reflect the chronic wasting state so common in rheumatoid arthritics rather than the direct consequence of the rheumatoid process itself. But many observers believe that, although these tests are in a strict sense not liver function tests, they can, nevertheless, be employed to test the functions of the liver. Some of these, notably the protein fractionation, cephalin flocculation, and thymol turbidity tests, reflect a qualitative and probably

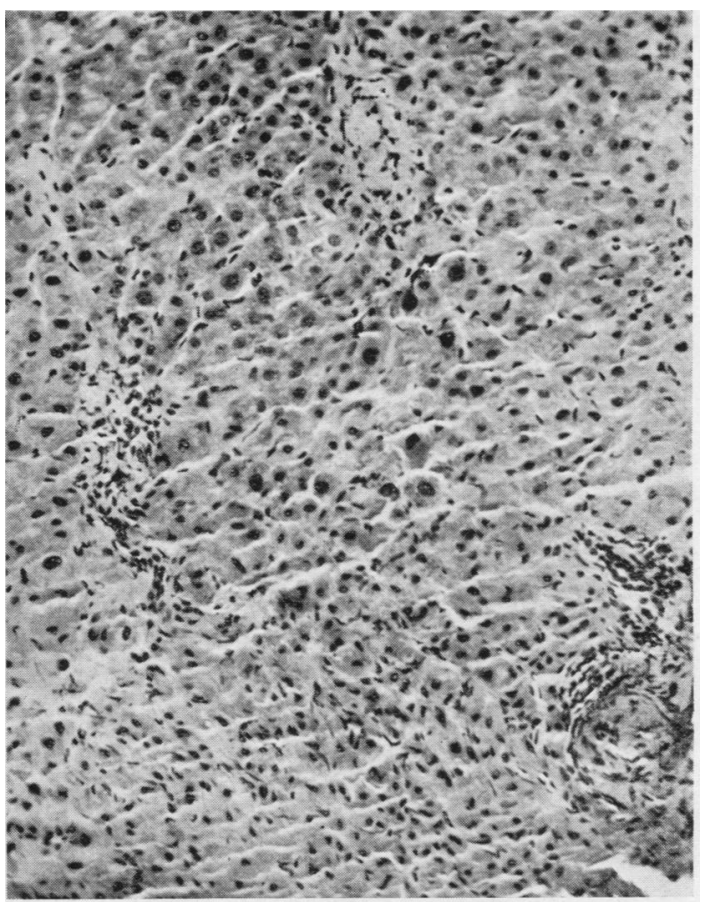

Fig. 2.-Case 6, showing variations in size and staining of nuclei, moderate increase of periportal fibrous tissue, and round cell infiltration.

a quantitative alteration in the serum proteins. Since the liver plays an important role in the elaboration of these proteins, and the serum albumin is thought to be formed only in the liver (Wright, 1952), it can be stated that abnormal values obtained by these tests can be considered to indicate disturbances in liver function. Though our results do not permit an unequivocal answer to the problem "of liver involvement in the rheumatoid process", they appear to justify the opinion that some of the functions of the liver are pathologically altered in patients suffering from rheumatoid disease.

\section{Summary}

(1) An attempt has been made to ascertain whether the liver is involved in patients with rheumatoid arthritis.

(2) Liver function tests were performed in 86 patients with rheumatoid arthritis, who had peripheral joint involvement, and in an additional fourteen patients who had only spinal involvement. Of the 86 patients with peripheral joint involvement, nine had spinal involvement also.

(3) Three patients died and liver tissue was obtained for post-mortem examination. In twelve 


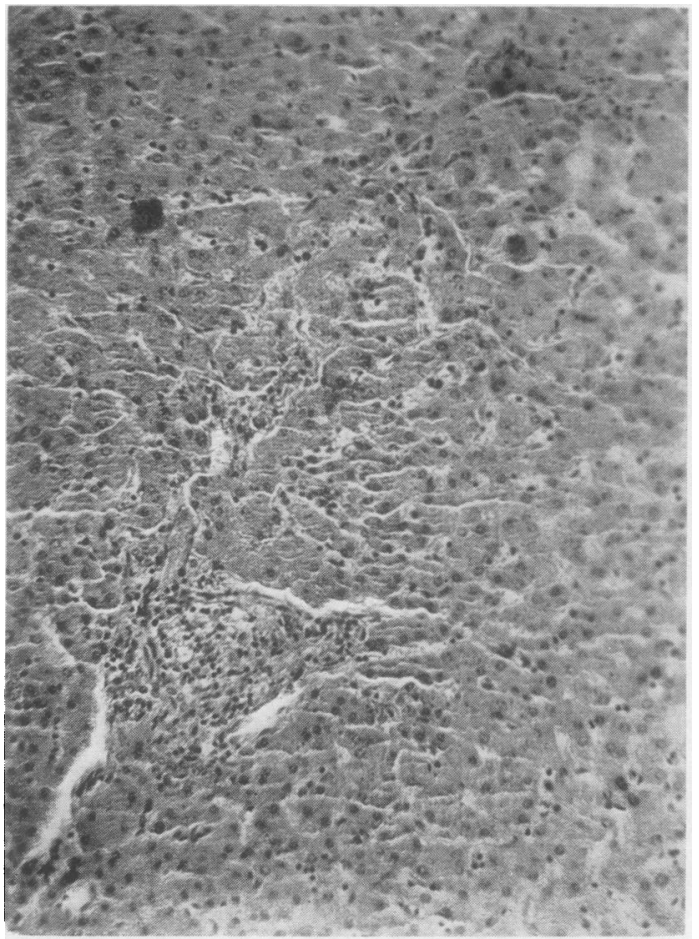

Fig. 3.-Case 13, periportal triad showing slight increase of fibrous tissue and round cell infiltration.

other patients liver tissue for examination was obtained by biopsy.

(4) There was a definite relationship between the severity of the disease and the frequency of abnormal results in liver function tests. Elevation of the serum globulin level and depression of the serum albumin level were the most frequently found abnormalities, closely followed by abnormalities in cholesterol, cephalin flocculation, and thymol turbidity.

(5) Histological study of liver tissue revealed definite abnormal morphological alterations only in two out of the fifteen available specimens. These changes are briefly described. The lack of correlation between the clinical and laboratory evidence of liver involvement and the histological appearance of liver tissue is briefly discussed.

(6) Although the results obtained do not allow a definite answer to the problem proposed, the authors believe them to justify the opinion that the functions of the liver are impaired in persons affected by rheumatoid disease.

We express our grateful appreciation to Dr. Joseph $\mathbf{M}$. Young, pathologist, for examining the slides, and to the Medical Illustration Laboratory, Veterans Administra-

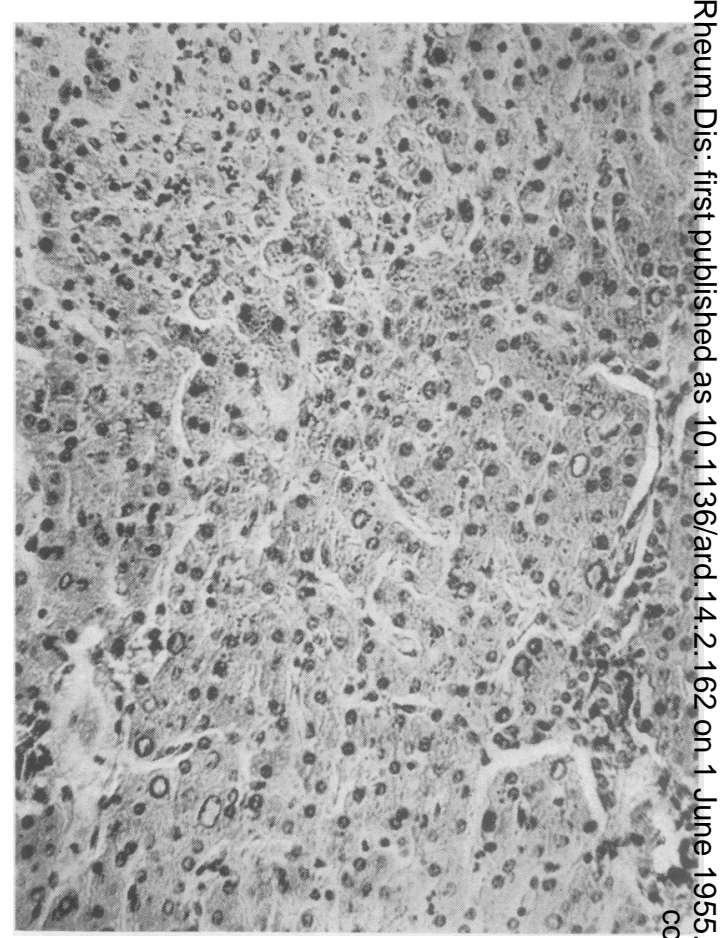

Fig. 4.-Case 14, showing congestion and polymorphonuefer infiltration of central zone area.

tion Medical Teaching Group Hospital, Memphis, 1 , Tennessee, for the preparation of the illustrations.

\section{REFERENCES}

Archer, B. H. (1951). Ann. intern. Med., 34, 1173.

Baggenstoss, A. H., and Rosenberg, E. F. (1943). Arch. Path

Bloor, W. R., Pelkan, K. F., and Allen, D. M. (1922). J. biol. Chem, 52, 91 .

Bodansky, A. (1933). Ibid., 101, 93

Carter, A. B., and Maclagan, N.F. (1946). Brit. med. J., 2, 80.

Davis, J. S., Jr. (1936). J. Lab. clin. Med., $21,478$.

Evelyn, K. A., and Malloy, H. T. (1937). J. biol. Chem., 119, 481. 윽

Fisher, B. (1947). Amer. J. clin. Path., 17, 471. Chem., 119, 481. 马

Franklin, M., Popper, H., Steigmann, F., and Kozoll, D. D. (1948ð J. Lab. clin. Med., 33, 435.

Hanger, F. M. (1939). J. clin. Invest., 18, 261.

Hench, P. S. (1940). Med. Clin. N. Amer., 24, 1209.

Kalbak, K. (1951). Annals of the Rheumatic Diseases, 10, 182.

Ley, A. B., Lewis, J. H., and Davidson, C. S. (1946). J. Lab. clin?. Med., 31, 910. “D.

Lichtman, S. S. (1942). "Diseases of the Liver, Gallbladder, and Bile Ducts", 1 st ed., p. 250. Lea and Febiger, Philadelphia.
t, E. R., and Davis, A. E. (1953). Amer. J. med. Sci., 226, 5160 Movitt, E. R., and Davis, A. E. (1953). Amer. J. med. Sci., 226, 5160
Perlmann, G. E., and Kaufman, D. (1946). J. clin. Invest., 25, 931 . G
Popper, H. (1954). Amer. J. Med., 16, 98.

, Waldstein, S. S., and Szanto, P. B. (1950). Amer. J. clin. PathNS $20,724$.

Rawls, W. B., Weiss, S., and Collins, V. L. (1937). Ann. intern. Med WU 10,1021 .

Rose,,$\frac{}{1}$ (1939). Ibid., 12, 1455.

Rosenthal, S. M., and White, E. C. (1925). J. Amer. med. Ass. 84, 1112

Schmengler, F. E. (1952). Medizinische, 1, 1553. Schmengler, F. E. (1952). Medizinische, 1, 1553.
Steinbrocker, O., Traeger, C. H., and Batterman, R. C. (1949尔
J. Amer. med. Ass., 140, 659. Wolfson, W. Q., Cohn, E., Calvary, E., and Ichiba, F. (1948). Tech
Bull. Reg. Med. Tech., 18, 723.

Wright, S. (1952). "Applied Physiology", 9th ed., p. 831. Oxfor University Press, London. 
Le foie dans l'arthrite rhumatismale

\section{RÉSUMÉ}

(1) On a taché de trouver si le foie était impliqué chez les malades atteints d'arthrite rhumatismale.

(2) On fit des tests de la fonction hépatique chez 86 rhumatisants avec atteinte articulaire périphérique et chez 14 autres avec atteinte vertébrale seule. Chez 9 sur les 86 rhumatisants polyarticulaires il $y$ eut une atteinte vertébrale concomitante.

(3) On effectua un prélèvement de tissu hépatique à l'autopsie de 3 malades décédés et chez 12 malades vivants.

(4) On nota un rapport bien déterminé entre la sévérité de la maladie et la fréquence des résultats anormaux des tests de la fonction hépatique. L'augmentation du taux de la globuline sérique et la baisse de celui de l'albumine se virent le plus souvent, suivies de près par des chiffres anormaux du cholesterol, de la réaction de floculation de la céphaline et de la turbidité du thymol.

(5) A l'examen histologique, des altérations morphologiques du tissu hépatique ne furent trouvées que dans deux pièces sur les quinze disponibles. On présente une brève description de ces altérations. On discute sommairement l'absence d'un rapport entre les manifestations cliniques et de laboratoire de l'atteinte du foie et l'apparence histologique du tissu hépatique.

(6) Bien que les résultats obtenus n'offrent pas de solution claire du problème posé, les auteurs croient qu'ils justifient l'opinion que les fonctions du foie seraient altérées dans la maladie rhumatismale.

\section{El higado en la artritis reumatoide}

SUMARIO

(1) Se trató de comprobar si el hígado estaba implicado en los enfermos con artritis reumatoide.

(2) Se hicieron valoraciones de la función hepática en 86 enfermos con implicación articular periférica y en 14 con implicación vertebral sola. En 9 de los 86 con implicación periférica la espina participaba del proceso reumático.

(3) Se obtuvo tejido hepático de autopsias al morir 3 enfermos y de biopsias en doce casos.

(4) Se notó una relación determinada entre la severidad de la enfermedad y la frecuencia de los resultados anormales de las determinaciones de la función hepática. Halláronse más frecuentemente cifras altas de globulina sérica y bajas de albumina, seguidas de cerca por valores anormales del colesterol, de la reacción de floculación de la cefalina y de la turbiedad del timol.

(5) Histológicamente, alteraciones morfológicas del tejido hepático encontráronse tan solo en dos preparaciones de las quince obtenidas. Se presenta una breve descripción de estas alteraciones. Se discute brevemente la falta de correlación entre las manifestaciones clínicas y de laboratorio de la implicación del hígado y el aspecto histológico del tejido hepático.

(6) Aunque los resultados obtenidos no ofrecen una solución clara del problema puesto, los autores creen justificada la opinión de que las funciones del hígado están alteradas en la enfermedad reumática. 